\title{
Mesure des paramètres non dimensionmels des vortex de surface libre à proximité des prises horizontales et inversées verticalement
}

\section{The mon-dimensional parameters of free-surface vortices measured for horizontal and vertically inverted intakes}

\author{
H.O. Anwaar \\ Hydraulics Research Station, Wallingford, \\ England
}

Introduction

Les prises habituellement utilisées pour fournir l'eau nécessaire aux besoins domestiques et industriels devraient être conçues de façon à apporter un minimum de perturbations à l'appareillage hydraulique et aux installations annexes. Au cours des dernières années, une attention croissante a été apportée à la sureté de leur fonctionnement et par suite des règlements de sécurité rigoureux ont été imposés. L'une des sources de perturbation est l'apparition, à la surface libre, de vortex avec ou sans noyau d'air, dont la présence peut entrainer dans les pompes, les turbines et les canalisations, une perte de rendement, de la cavitation et des vibrations.

Le phénomène des vortex de surface libre est complexe et difficile à décrire en détail ; sa structure n'est en aucune façon entièrement comprise, ni physiquement, ni analytiquement ; c'est pourquoi un modèle réduit a été et sera fréquemment utilisé :

a) pour assurer le fonctionnement satisfaisant d'une prise et de ses installations annexes ;

b) pour trouver les mesures susceptibles d'éliminer les principales conditions indésirables de l'écoulement.

C'est presque devenu une routine, dans les grandes centrales, de faire une étude sur maquette (ci-après dénommée modèle) pour examiner les conditions d'écoulement dans la fosse de pompage et dans le canal d'amenée.

Il y a diverses forces qui régissent l'écoulement dans un vortex de surface libre, et il est impossible de les mettre toutes en jeu dans le modele. Il est donc essentiel de déterminer l'importance de l'erreur commise en appliquant au prototype les résultats du modèle, cette erreur dépendant entièrement des conditions de similitude géométrique et dynamique qui auront été réalisées. L'échelle choisie pour le modèle joue un rôle très important dans l'interprétation des résultats.

\section{Introduction}

Hydraulic intakes commonly used to supply water for domestic and industrial needs should be so designed to cause minimum disturbance in hydraulic machinery and related structures. In recent years increasing attention has been directed towards their operational reliability and therefore stringent safety regulations have been imposed. One of the sources of disturbance is the occurrence of free surface vortices with or without an air core, the presence of which can cause loss of efficien$c y$, cavitation and vibration in pumps, turbines and pipelines.

Free surface vortex phenomenon is complex and difficult to describe in detail, its flow structure is by no means fully understood physically as well as analytically, therefore a physical model has been and will be frequently employed :

a) to ensure the satisfactory performance of an intake and its related structure

b) to obtain remedial measures in eliminating the major undesirable flow conditions.

It becomes almost a routine procedure in large power plants to conduct a physical model study (hereafter called model) to examine flow conditions in the pumping pit and in the approach channel.

There are various forces dominating the flow in a free surface vortex, and it is impossible to include all these forces in the model. Thus it is essential to determine the magnitude of the error that will be involved when applying model results to the prototype which depend entirely on the conditions of geometric and dynamic similarity that have been achieved. The chosen model scale plays a very important part in the interpretation of results. 
Le but de cet article est :

a) de définir les diverses forces et variables géométriques qui régissent la formation des vortex de surface libre avec ou sans noyau d'air (ci-après dénommés vortex) ; b) de les présenter sous forme non dimensionnelle, ce qui peut être résolu expérimentalement.

La seconde partie de cet article traite des résultats expérimentaux obtenus à partir de mesures effectuées sur des prises horizontales ou inversées verticalement, et dont certains ont déjà été publiés [4]. On espère que les résultats présentés ici seront utiles dans les études sur modèle réduit, et auront une valeur pratique pour les ingénieurs d'études. Il faut souligner que ces résultats ont été obtenus à partir d'une étude générale de base, et ne peuvent fournir une solution détaillée à toutes les conditions possibles qui se présentent dans une installation en vraie grandeur.

\section{Analyse}

Les paramètres fondamentaux qui régissent la formation des vortex de surface libre sont habituellement déterminés en supposant que l'écoulement permanent est symétrique par rapport à un axe, et que le fluide est incompressible. Il est en outre supposé que l'écoulement du vortex est laminaire $[1,21,23,29]$, c. à d. affecté par la seule viscosité du fluide d'essai, et que la tension superficielle n'intervient que dans le cas où il y a une dépression de surface ou un noyau d'air. Les résultats expérimentaux ont montré $[2,3,4]$ que la force d'un vortex est affectée par la rugosité des parois rigides, mais que les configurations de l'écoulement et la répartition des composantes de la vitesse restent inchangées. Ce résultat, ainsi que celui de Durgin et al. $[12,13\}$, obtenus par une étude sur maquette en laboratoire, confirment I'hypothèse ci-dessus que l'écoulement dans un vortex est toujours affecté par la viscosité du fluide [1, 2], même quand le nombre de Reynolds (défini ci-après) devient très grand $\left(R_{R} \rightarrow \infty\right)$. Il est par suite légitime d'utiliser les paramètres non dimensionnels qui ont été obtenus à partir d'une considération théorique basée sur un écoulement laminaire appliquant les équations de Navier-Stokes. [2, 11, 14, 16, 23, 26, 28]. Ces paramètres, ainsi que ceux qui représentent la tension superficielle, le rendement de la prise et sa géométrie, peuvent être traduits par l'expression suivante :

$$
f\left(\frac{\Gamma r_{0}}{Q}, \frac{Q}{\nu h}, \frac{r_{0}}{h}, W, C, \frac{h}{D}, \frac{b}{D}, \frac{x}{D}\right)=0
$$

Dans l'équation (1), $f$ représente une fonction universelle des arguments entre parenthèses, qui constituent l'ensemble complet des produits non dimensionnels des variables concernant la formation des vortex et le rendement de la prise. On donnera tout d'abord une description de ces paramètres non dimensionnels, après quoi on identifiera les paramètres dépendants et indépendants qui régissent la formation des vortex. Le premier terme entre parenthèses représente de façon non dimensionnelle la circulation $\Gamma=V_{\theta} r$, sans laquelle un vortex ne peut prendre naissance $[3,4,17,13,14$, $16,29,30]$. Il a été trouvé expérimentalement que la
The purpose of this paper is:

a) to define the various forces and geometrical variables that govern the formation of free surface vortices with or without an air core (hereafter called vortices), b) to present them in non-dimensional forms, which can be determined experimentally.

The second part of the paper deals with the experimental results obtained from measurements conducted on horizontal and vertically inverted intakes, some of which have been published previously [4]. It is hoped that the results presented here will be of use in model studies and also of practical value to design engineers. It must be stressed that these results were obtained from a general basic study and cannot provide a detailed solution to all possible conditions that occur in a full scale layout.

\section{Analysis}

The fundamental parameters that govern the formation of free surface vortices will be determined by assuming that the steady flow is axisymmetric and the fluid is incompressible. Furthermore, it will be assumed that vortex flow is laminar $[1,21,23,29]$, i.e. affected by the viscosity of the test fluid alone, and that surface tension acts only when there is a surface depression or an air core. The experimental results showed $[2,3,4]$ that the strength of a vortex is affected by the roughness of rigid boundaries but that the flow patterns and the distribution of velocity components remain unchanged. This result together with that of Durgin et al. $[12,13]$ obtained from a laboratory model study, supports the above assumption that the flow in a vortex is always affected by the fluid viscosity [1, 2], even when the Reynolds number (defined later) becomes very large, $\left(R_{R} \rightarrow \infty\right)$. Hence, it is legitimate to use the non-dimensional parameters that were obtained from a theoretical consideration based on laminar flow using Navier-Stokes equations $[2,11,14,16,23,26,29]$. These parameters together with those representing surface tension, the efficiency of an intake and the intake geometry, can be stated in the following expression :
In Eq (1) $f$ denotes a universal function of the arguments in the parenthesis representing the complete set of non-dimensional products of the variables that affect the onset of vortices and the efficiency of an intake. First, a description of these non-dimensional parameters will be given after which the dependent and independent parameters that govern the formation of vortices will be identified. The first term in the brackets describes the circulation, $\Gamma=V_{\theta} r$, non-dimensionally, without which a vortex cannot form $[3,4,17,13,14,16,29,30]$ It was found experimentally that the depth of a surface depression and the size of the air core increase, with the 
profondeur d'une dépression de surface et les dimensions du noyau d'air augmentent avec l'accroissement de la composante tangentielle de la vitesse, $V_{\theta}$, mesurée au rayon $r$. Ce dernier peut être pris à une distance où la circulation devient constante $[2,4] . Q$ est le débit à l'entrée d'une section transversale $A\left(A=\frac{\pi D^{2}}{4}\right.$ pour une prise circulaire de diamètre $\mathrm{D}$, ou d'un diamètre équivalent pour une section non circulaire (. Il existe différentes façons pour un écoulement entrant d'acquérir une circulation, suivant la position de la prise, la topographie locale et les parois $[10,12,15,17]$, ainsi que suivant la répartition des vitesses et sa variation dans l'écoulement amont. Il y a des cas où les circulations ainsi produites sont assez fortes pour former un vortex $[9,10,17]$. Il a également été suggéré qu'une chute de pression locale pouvait provoquer une circulation, et par suite un vortex $(5,22)$.

La circulation $\Gamma$ peut être mesurée sur un modèle ou un prototype à un rayon convenable. Il a été proposé en variante que, dans les cas où $\Gamma$ n'est pas facile à mesurer, sa valeur puisse être estimée en définissant $V_{\theta}$ d'après les filets de l'écoulement amont [21]. Il semble que, lorsqu'un vortex se forme, les filets dans le champ de l'écoulement puissent être assimilés à un genre de spirale logarithmique d'angle constant $\phi$, de sorte que $V_{\theta}=\frac{Q}{A_{c}} \tan \Phi$, où $A_{c}$ est la section transversale de l'écoulement amont, et l'angle $\Phi$ reste constant légèrement près de la paroi rigide. Quand l'angle $\Phi \cong$ $\frac{\pi}{2}$, cette relation indique que l'écoulement amont se présente à la prise radialement et sans remous, et que la composante radiale de la vitesse $V_{r}=\frac{Q}{A_{c}}$. Pour $\Phi \cong 0$, la relation ci-dessus indique que les filets nesont pas dirigés vers la prise, mais parallèles à cette dernière.

Le deuxième terme de l'équation (1) renferme la viscosité cinématique $\nu$ et, à cause de sa forme, est dénommé nombre de Reynolds radial $R_{Q}$; le débit effectif est réglé par l'écoulement radial qui se produit près de la surface libre et de la paroi rigide $[1,2,4]$. Ce paramètre joue un rôle important dansla formation des vortex, aussi bien dans le modèle que dans le prototype. Le troisième terme de l'équation (1), $\frac{r_{0}}{h}$, traduit la similitude géométrique des vortex [4]. La profondeur d'immersion $h$ représente l'échelle verticale, et $r_{0}$ est une échelle radiale ou horizontale définie comme la distance radiale mesurée entre l'axe du vortex et un point où se produit un changement dans le champ de l'écoulement ; ce point peut être soit un point où les composantes tangentielles ou radiales de la vitesse passent par un maximum, soit un point où la composante axiale de la vitesse est nulle. Les mesures [2, 11, $24,27,29]$ ont montré que la courbe de la vitesse verticale passe d'une valeur positive à une valeur négative pour un certain nombre de distances radiales, ce qui indique un mouvement vers le haut et vers le bas dans le champ de l'écoulement. increase of the tangential velocity component, $V_{\theta}$, measured at radius $r$. This can be taken at a distance where the circulation becomes a constant $[2,4] Q$ is the discharge through the intake of a cross-sectional area $A\left(A=\frac{\pi D^{2}}{4}\right.$ for a circular intake of diameter $D$, or the equivalent diameter for non-circular intake). There are a number of ways that an oncoming flow can acquire a circulation, from the position of the intake and local topography and boundaries $[10,12,15,17]$, also from the velocity distribution and its variation in the approach flow. There are cases in which circulations set up in these last ways are strong enough to form a vortex $[9,10,17]$ It has also been suggested that a local pressure drop can produce a circulation and hence $a$ vortex $[5,22]$

The circulation $\Gamma$ can be measured in a model or the prototype at a convenient radius. Alternatively it has been proposed that when $\Gamma$ is not easy to measure its value can be estimated by defining $V_{\theta}$ from the streamlines of an approach flow [21]. There is some indication that when a vortex forms, the streamlines in the flow field can be approximated by a logarithmic spiral type of constant angle $\phi$ so that $V_{\theta}=\frac{Q}{A_{c}}$ tan $\phi$ where $A_{c}$ is a cross-sectional area of the approach flow and the angle remains a constant throughout the submergence depth $^{(20)}$ but increases slightly near the rigid boundary. When the angle $\phi \approx \frac{\pi}{2}$ this relation indicates that the oncoming flow approaches the intake radially without swirl, and the velocity component in the radial direction $V_{r}=\frac{Q}{A_{c}}$. For $\phi \approx 0$ the above relation indicates that the streamlines are not directed towards but are parallel to the intake.

The second term in Eq (1) contains the kinematic viscosity $\nu$ and because of its form it is termed the radial Reynolds number $R_{Q}$; effective discharge is controlled by the radial flow that occurs near the free surface and the rigid boundary $[1,2,4]$. This parameter plays an important part in the onset of vortices in both model ana prototype. The third term in $E q(1), \frac{r_{0}}{h}$, denotes the geometric similarity of vortices [4]. The submergence depth, $h$, represents the vertical scale and $r_{0}$ is a radial or a horizontal scale defined as the radial distance measured from the vortex axis to a point at which a change in the flow field takes place, this point can be either where the tangential or the radial velocity components become a maximum $[2,24]$, or alternatively the points with a zero axial velocity component. Measurements $[2,11,24,27,29]$ have shown that the vertical velocity profile passes from a positive to a negative value at a number of radial distances, indicating an upward and downward motion in the flow field. 
La détermination de $r_{0}$ de cette façon n'est pas une tâche aisée, car elle exige des mesures détaillées de la vitesse. Mais les résultats expérimentaux ont montré que, dans le cas d'un fort vortex à gros noyau d'air, le maximum de la courbe de la vitesse tangentielle se produit pour un rayon comparable à celui de la prise $[2,30]$, c'est-à-dire $r_{0}=\frac{D}{2}$. De plus, les résultats expérimentaux $[4,6]$ ont montré que le rayon d'une dépression superficielle, ainsi que celui des vortex à noyau d'air mince, mesurés près de la surface libre, peuvent être pris comme échelle radiale $r_{0}$, qui varie directement avec $h$ et la cote $b$ de la prise, mesurée à partir du fond. Cette variation fonctionnelle et la définition des vortex à noyau mince seront données ultérieurement. Dans l'équation (1), $W$ représente le nombre de Weber, définir par
To determine $r_{0}$ in these ways is not an easy task, because it requires detailed velocity measurements. But the experimental results have shown that in the case of a strong vortex with a large air core, the maximum of the tangential velocity profile occurs at a radius comparable to that of the intake $[2,30]$ i.e. $r_{0} \approx D / 2$. Furthermore experimental results $[4,6]$ showed that the radius of a surface depression, also that of vortices with a slender air core, measured near the free surface, can be taken as the radial scale $r_{0}$ which varies directly with $h$ and the intake clearance, $b$, measured from the floor. This functional variation and the definition of vortices with a slender core will be given later. In Eq (1) $W$ denotes the Weber number defined:

$$
W=\frac{\rho}{\sigma} V^{2} h
$$

où $\sigma$ est la tension superficielle du fluide d'essai de densité $\rho$, et $V=\frac{Q}{A}$ est la vitesse moyenne mesurée dans la prise.

L'effet de la tension superficielle devient apparent quand une dépression apparait à la surface libre, et son influence est négligeable quand la surface libre est plane. Ainsi qu'il a été signalé précédemment, et qu'il pourra être déduit des résultats expérimentaux indiqués ci-après, la profondeur d'une dépression superficielle, $h_{d}$, ou la dimension d'un noyau d'air, et par conséquent la courbure de la surface libre, croissent presque linéairement avec l'augmentation de la circulation $\Gamma$.

Ii y a donc lieu de tenir compte de la circulation de l'écoulement amont lorsqu'on présente l'effet du nombre de Weber sur les vortex $[17,18]$, ainsi qu'il en sera discuté plus loin. Dans l'équation (1), $C=Q / A \sqrt{2 g h}$ est le coefficient de débit, (rendement de la prise), et $g$ est l'accélération de la pesanteur. Dans l'équation (1), $\frac{h}{D}$ est le paramètre d'immersion ; l'effet de sa variation sera indiqué ultérieurement. Enfin, dans l'équation (1) $\frac{b}{D}$ et $\frac{x}{D}$ sont des paramètres non dimensionnels représentant la similitude géométrique des frontières, $x$ étant la distance à partir de la paroi.

On peut déduire des définitions ci-dessus que les quatre premiers paramètres non dimensionnels de l'équation (1) indiquent la similitude géométrique et dynamique des vortex. Ces paramètres renferment les forces de viscosité et la tension superficielle, et par conséquent seront considérés, ainsi que les trois derniers paramètres de l'équation (1), comme des paramètres indépendants dans les phénomènes de vortex. La variation de tous ces paramètres agit sur le rendement de la prise, donné par $C=Q / A \sqrt{2 g h}$, qui est donc un paramètre dépendant.

Tous ces paramètres définis dans l'équation (1) ont été déterminés expérimentalement pour les prises horizontales et inversées verticalement, avec les résultats donnés ci-dessous : where $\sigma$ is the surface tension of a test fluid hoving mass density $\rho$ and $V=Q / A$ is the mean velocity measured in the intake.

The effect of surface tersion becomes apparent when a depression appears at the free surface and its influence is negligible when the free surface is level. As mentioned previously, and as can also be seen from the experimental results shown later, the depth of a surface depression $h_{d}$, or the size of an air core, and hence the free surface curvature increases almost linearly with the increase of circulation $\Gamma$.

The circulation of the approach flow needs to be considered therefore in presenting the effect of the Weber number on vortices $[17,18]$, as will be discussed later. In $E q(1), C=Q / A \sqrt{2 g h}$ is the coefficient of discharge (intake efficiency) and $g$ is the acceleration due to gravity. Also in Eq $(1) \frac{h}{D}$ is the submergence parameter, the effect of its variation will be shown later. Finally in $E q(1) \frac{b}{D}$ and $\frac{x}{D}$ are non-dimensional parameters describing the geometrical similarity of the boundaries, $x$ being the side wall clearance.

From the above description it can be seen that the four first non-dimensional parameters in $E q$ (1) indicate geometric and dynamic similarity of vortices. These parameters contain viscous forces and surface tension, hence, together with the last three parameters in Eq (1) will be considered as independent parameters in vortex phenomena. The variation of all these will affect the intake efficiency described by $C=Q / A \sqrt{2 g h}$, which is thus a dependent parameter.

All these parameters defined in Eq (1) were determined experimentally for horizontal and vertically inverted intakes with results given below. 


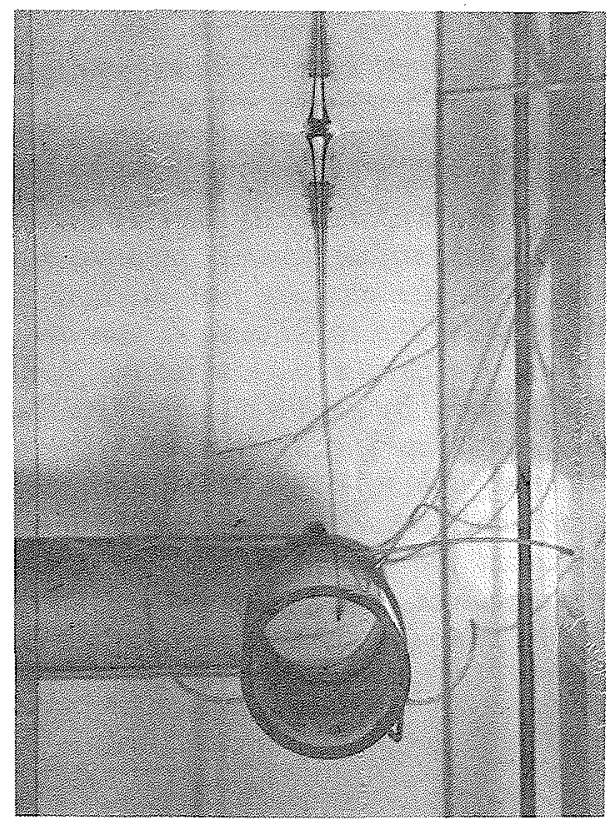

Horlzontal Intake

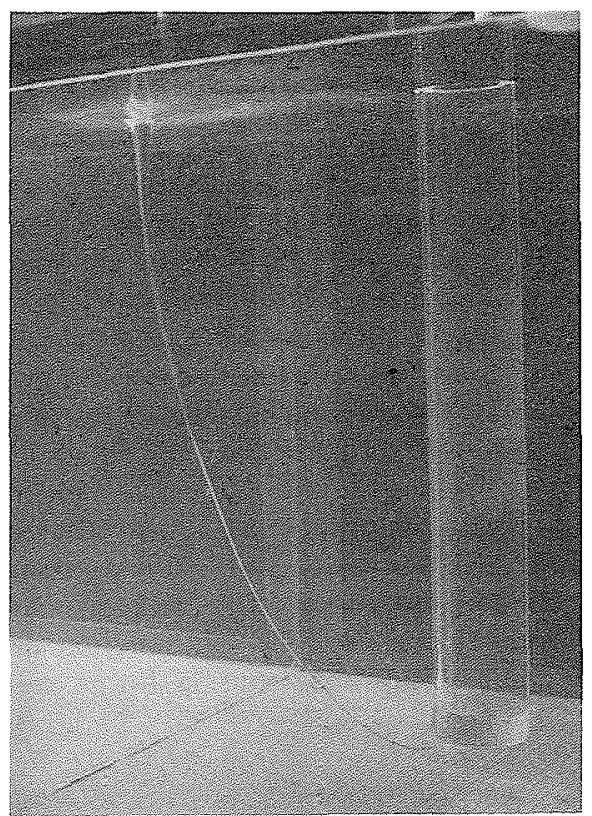

Vertically inverted intake

Figure 1 - Typical free surface vortices at hydraulic intakes.

\section{Résultat expérimentaux}

L'étude expérimentale a été effectuée dans un canal à parois de verre de $13 \times 0,92 \times 0,92 \mathrm{~m}$ de profondeur à fond lisse. Les prises horizontales et inversées verticalement étaient placées près de l'extrémité du canal. Le courant amont dans le canal était uniforme, sans circulation préalable. Les prises étaient des tubes transparents dont le diamètre intérieur était $D=50,8 ; 76,2$ et $101,6 \mathrm{~mm}$, l'épaisseur des parois $6,4 \mathrm{~mm}$, et le bord

\section{Experimental results}

The experimental study was carried out in a glasswalled flume of dimensions $13 \times 0.92 \times 0.92 \mathrm{~m}$ deep with a smooth floor. The horizontal and vertically inverted intakes were placed near the flume end. The approach flow in the flume was uniform, without precirculation. The intakes were transparent pipes of internal diameter $D=50.8,76.2$ and $101.6 \mathrm{~mm}$, with a wall thickness of $6.4 \mathrm{~mm}$ and a rounded edge. Some

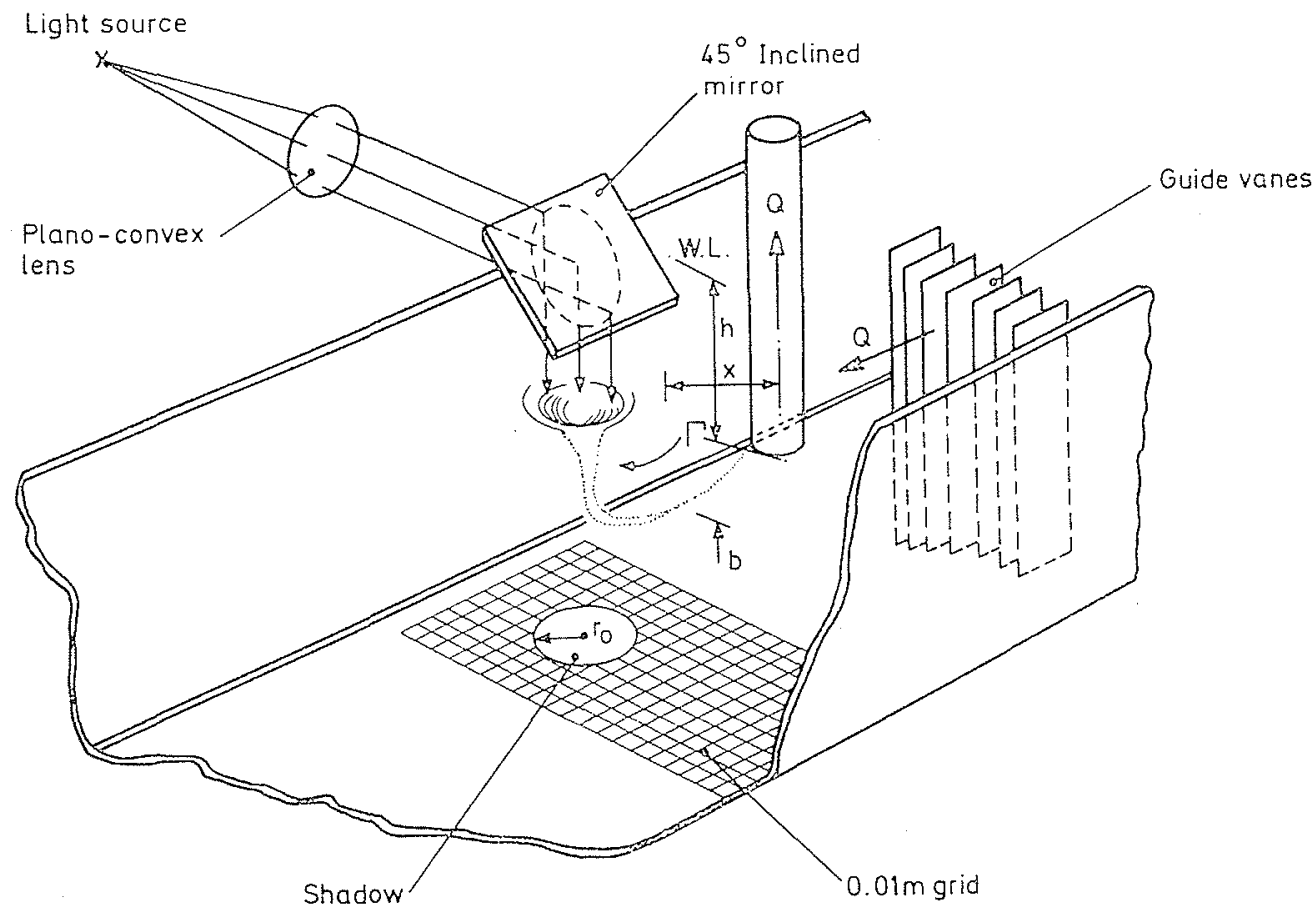

Figure 2 - Diagrammatic sketch of the experimental set up and definition of terms. 
arrondi. Certaines expériences furent effectuées avec un orifice divergent de $76,2 \mathrm{~mm}$. Les expériences furent faites avec la prise horizontale soit à ras de la paroi du canal, soit en saillie de $0,3 \mathrm{~m}$ par rapport à cette dernière. Les deux types de prises pouvaient être levés ou abaissés pour faire varier leur distance aux parois $b$ et $x$.

Les vortex de surface libre mentionnés ici sont ceux dont le noyau d'air mince atteignait juste l'orifice de la prise (voir fig. 1). L'échelle radiale $r_{0}$ était déterminée par le rayon d'une ombre circulaire sur le fond du canal, produite en envoyant un faisceau de lumière parallèle à travers la surface libre (fig. 2). On peut raisonnablement supposer que la zone dans laquelle l'inclinaison de la surface pourrait réfracter la lumière de façon importante serait aussi celle qui contient le mouvement effectif du vortex. Les mesures ont montré que la circulation $\Gamma$ était en fait fonction de ce rayon $r_{0}$ de l'ombre, exprimée sous la forme sui. vante :

$$
\Gamma=\alpha\left(\frac{g}{h_{0}}\right)^{1 / 2} r_{0}^{2}
$$

où $\alpha=0,86$ est une constante expérimentale non dimensionnelle, dépendant principalement du système optique ; $h_{0}=h+b$ (voir fig. 2). On peut voir dans l'équation (3) que $\Gamma$ est une constante pour un essai donné.

Il a été trouvé que le type de vortex décrit ci-dessus a tendance à se déplacer autour de la prise, ce qui rend extrêmement difficile la mesure du rayon $r_{0}$ de l'ombre. Afin de faciliter les mesures et de simuler une gamme de experiments were conducted with a bellmouth entry to the $76.2 \mathrm{~mm}$ intake. The experiments were carried out with the horizontal intake flush to the flume wall and also with it projecting $0.3 \mathrm{~m}$ into the flume. Both types of intakes could be raised or lowered to obtain various intake boundary distances, $b$ and $x$.

The free surface vortices reported here were those with a slender air core just reaching the intake lip. (See fig. 1). The radial scale $r_{0}$ was determined as the radius of a circular shadow on the flume floor which was produced by sending a beam of parallel light through the free surface (fig. 2). It is reasonable to assume that the area within which the inclination of the surface could significantly refract the light would also be that which contained the effective vortex motion. The measurements showed that the circulation $\Gamma$ was indeed a function of this shadow radius $r_{0}$ described in the following form [4] i.e. where $\alpha=0.86$, is a dimensionless experimental constant, depending mainly on the optical system; $h_{0}$ the total submergence depth $h_{0}=h+b$ (see fig. 2). It can be seen from $E q(3)$ that $\Gamma$ is a constant for an experimental run.

It was found that the type of vortices described above tend to wander round the intake making the measurement of the shadow radius $r_{0}$ extremely difficult. In order to facilitate measurements and to simu-

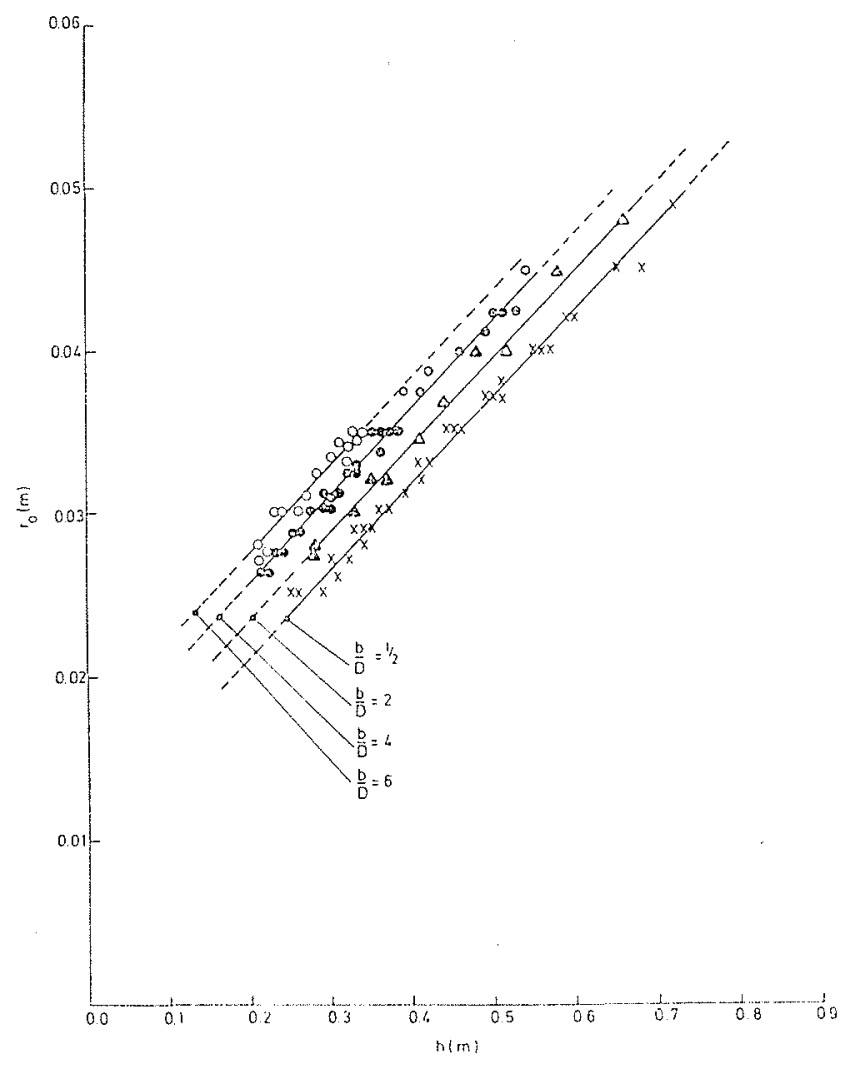

Figure 3 - Linear varaition of shadow radius with submergence depth for horizontal intake. 
conditions d'écoulement, un ensemble d'aubes directrices fut mis en place autour de la prise horizontale, ou en travers du canal dans le cas de la prise verticale inversée (voir fíg. 2). En calant ces aubes à des angles déterminés, on pouvait produire des vortex stables d'intensités diverses.

La courbe du rayon mesuré $r_{0}$ de l'ombre, considéré comme le rayon réel du vortex, a été tracée en fonction de la profondeur d'immersion $h$ pour diverses valeurs de $b$ $\frac{D}{D}$, et les résultats concernant les prises horizontales apparaissent sur la figure 3 . On peut voir que $r_{0}$ croît linéairement avec la profondeur d'immersion $h$ ainsi qu'avec la hauteur $b$ de la prise. La relation empirique suivante a été trouvée par application linéaire des moindres carrés aux valeurs mesurées : late a range of flow conditions a guide vane array was placed around the horizontal intake or across the flume in the case of vertically inverted intake (see fig. 2). By setting the guide vanes at specific angles it was possible to produce stable vortices of various strengths.

The measured shadow radius $r_{0}$, as the effective radius of the vortex, was plotted against the submergence depth $h$ for various $\frac{b}{D}$-values and the results for horizontal intakes are shown in figure 3. It can be seen that $r_{0}$ increases linearly with the submergence depth $h$ and also with the intake height $b$. The following empirical relation was found from a least square linear fit to the measured data, i.e.

$$
r_{0}=\alpha_{H} h+\beta_{H}
$$

où $\alpha_{H}=0,054$ est une constante empirique de la prise horizontale. Les valeurs empiriques de $\beta_{H}$ pour les diverses valeurs non dimensionnelles de la hauteur de la prise $\frac{b}{D}$ données dans la figure 3 peuvent s'exprimer sous la forme suivante :

$$
\beta_{H}=0.12 \frac{b}{D}+1.0
$$

Des résultats semblables à ceux qui apparaissent sur la figure 3 ont été obtenus pour une prise inversée verticalement. Par application linéaire des moindres carrés, il a été trouvé que $\alpha_{v}=0,06$, et que l'expression de $\beta_{V}$ est where $\alpha_{H}=0.054$ is an empirical constant for horizontal intake. The empirical $\beta_{H}$ - values for various non-dimensional intake height $\frac{b}{D}$ given in figure 3 can be expressed in the following form :

$$
\beta_{V}=0.143 \frac{b}{D}+0.89
$$

Les unités dans les équations (5) et (6) sont exprimées en mètres, et la différence entre les constantes qui se trouvent dans les équations (4) et (6) peut être attribuée aux différents types de vortex qui se forment à ces prises (voir fig. 1). Ceci sera discuté ultérieurement. Les résultats expérimentaux ont montré que ces constantes étaient indépendantes de la distance de la paroi $x$. Noter que les équations (4) et (6) peuvent s'appliquer aux cas où la circulation acquise de l'écoulement amont est assez forte pour produire une ombre de rayon $r_{0}$.

Des valeurs mesurées ont été déduits les paramètres non dimensionnels de l'équation (1) pour les deux types de prises, et les résultats sont donnés ci-après : On s'efforcera d'abord de montrer l'effet de la viscosité du fluide sur la formation du vortex

a) qui est essentiel pour la conception des études sur maquette et,

b) pour appuyer l'hypothèse faite précédemment que l'écoulement est toujours affecté par la viscosité.

C'est pourquoi la courbe du nombre de Reynolds radial $R_{R}$ a été tracée en fonction du paramètre de circulation $\Gamma r_{0} / Q$, et les résultats apparaissent sur les figures 4 et 5 : les lignes pleines sont tracées à titre d'exemple.

Sur la figure 4 apparaissent également les résultats des dépressions superficielles ("fossettes") pour
Similar results to those shown in figure 3 were obtained for a vertically inverted intake. From a least square linear fit to the measured data it was found that $\alpha_{V}=$ 0.06 and $\beta_{V}$ expression is

The units in Eqs (5) and (6) are in metres and the difference between the constants occurring in Eqs(4)(6) can be attributed to the different types of vortices that, form at these intakes (see fig. 1). This will be discussed later. The experimental results showed that these constants were independent of the wall clearance $x$. Note that Eqs (4) - (6) are applicable to the cases in which the acquired circulation of the oncoming flow is strong enough to produce a shadow of radius $r_{0}$.

From the measured data the non-dimensional parameters of Eq (1) were evaluated for the two types of intakes and the results are given below: First an attempt was made to show the effect of the fluid viscosity on the vortex formation which:

a) is essential for the design of model studies ; and

b) to support the assumption made previously that the flow is always affected by viscosity.

Accordingly the radial Reynolds number $R_{R}$ was plotted against the circulation parameter $\Gamma_{0} / Q$ and the results are shown in figures 4 and 5 : the solid lines are drawn by inspection.

In figure 4 are also shown the results of surface depressions (dimples) for a dimple depth $h_{d}-$ to - 


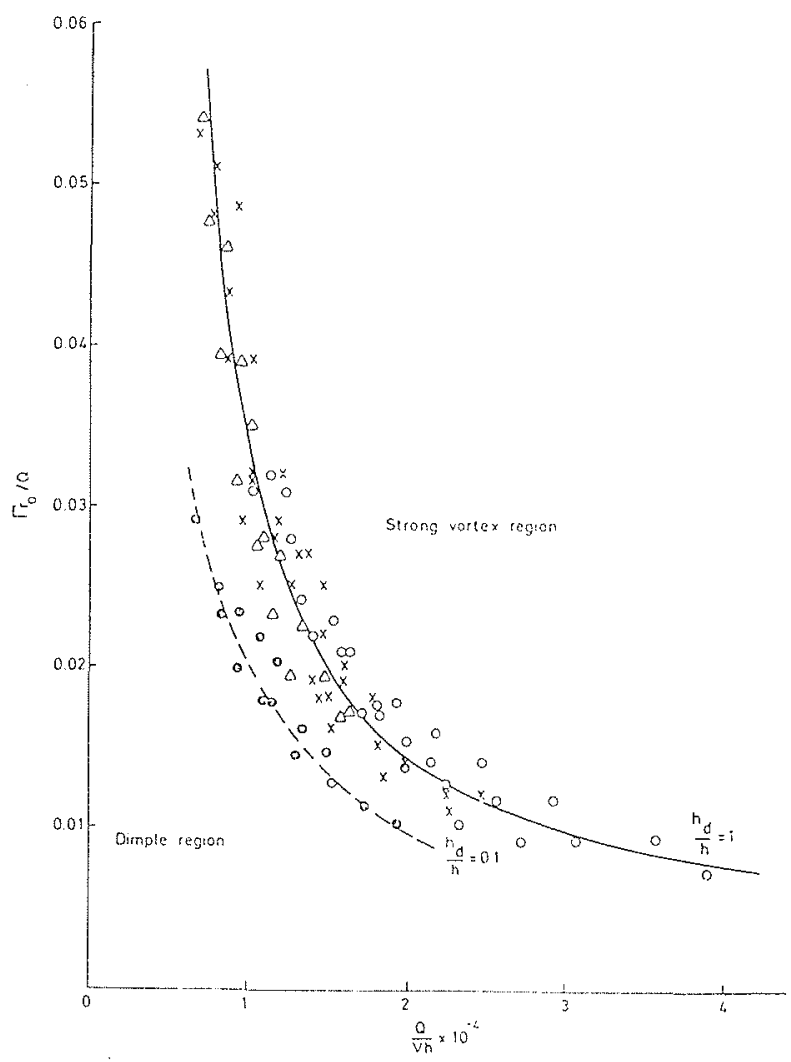
Figure 4 - Boundary of three different types of free surface vortex at horizontal intake, $\frac{1}{2} \leqslant \frac{b}{D} \leqslant 6, x=0$ and $0.30 \mathrm{~m}$, for symbols
see fig. 5 .

un rapport de 0,1 entre la profondeur de la fossette $h_{d}$ et $h$. Les dépressions formées à proximité des prises verticalement inversées n'étaient pas assez stables pour permettre de prendre des mesures. Elles deviennent bientôt soit un vortex à noyau d'air, soit une dépression de faible profondeur. Les valeurs portées sur les $h$ ratio of 0.1. Dimples formed at vertically inverted intakes were not stable enough for measurements to be taken. They soon become either a vortex with an air core, or a shallow depression. The data shown in Figures 4 and 5 gather together quite well, hence it can be concluded that the non-dimensional parame-

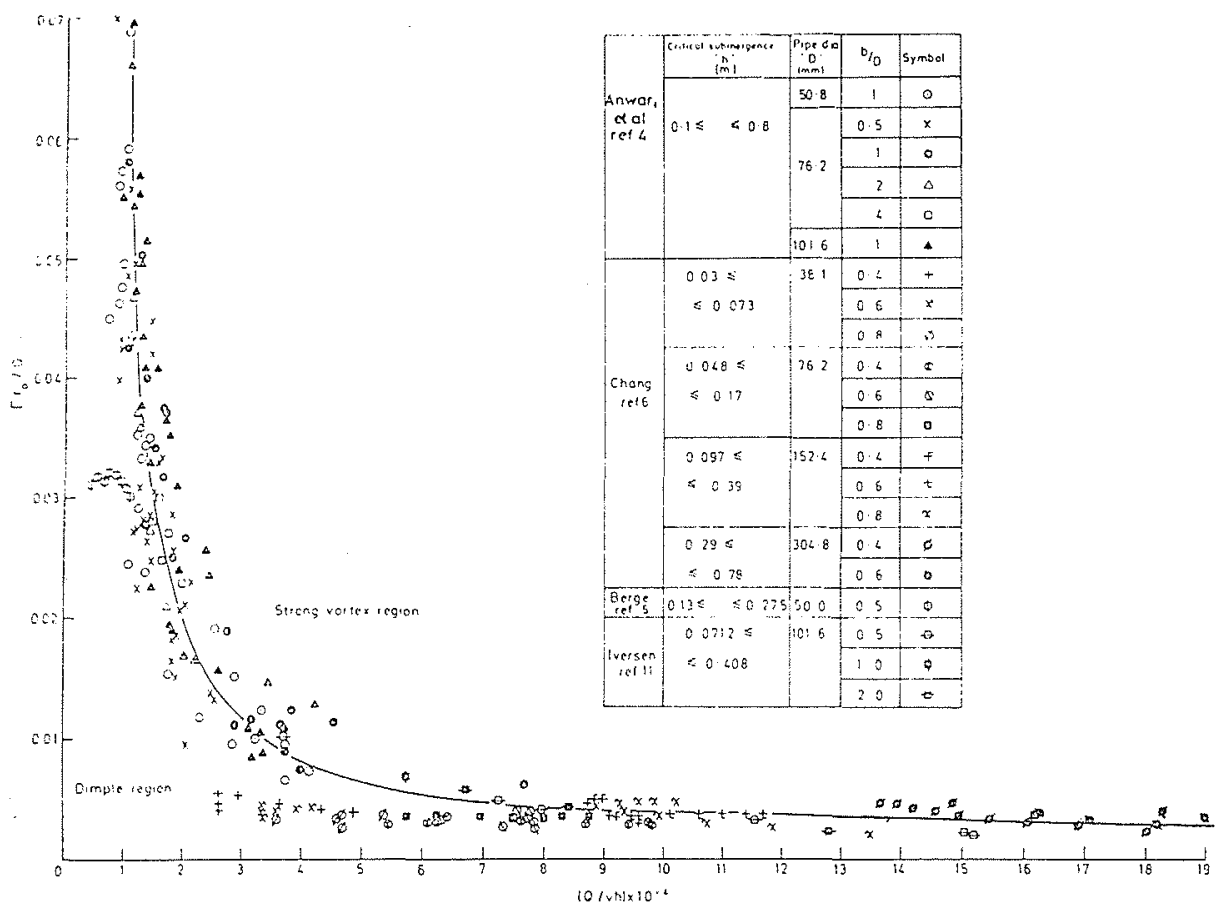

Figure 5 - Boundary of three different types of free surface vortex formed at vertically inverted intake, $1 \leqslant \frac{x}{D} \leqslant 9$. 
figures 4 et 5 sont assez concordantes, d'où l'on peut conclure que les paramètres non dimensionnels représentant les effets de la circulation et de la viscosité du fluide sont acceptables.

Les figures 4 et 5 montrent que le paramètre de circulation décroit d'abord rapidement avec l'augmentation du nombre de Reynolds radial $R_{R}$; sa variation devient plus lente quand $R_{R}$ augmente davantage, et la figure 5 montre clairement que le paramètre de circulation ne devient jamais indépendant du nombre de Reynolds radial, résultat qui confirme l'hypothèse faite précédemment que l'écoulement dans un vortex est de type laminaire et toujours affecté par la viscosité du fluide. Ces chiffres font en outre ressortir les limites entre trois régions, à savoir les vortex à large noyau d'air, les vortex à noyau d'air mince, et la région des fossettes. Ces trois types de vortex peuvent se présenter pour diverses valeurs du nombre de Reynolds radial $R_{R}$ quand le paramètre de circulation est faible : ceci a d'assez fortes chances de se produire dans les études sur maquette à petite échelle, dans lesquelles le paramètre de circulation est habituellement faible. Les figures 4 et 5 montrent également que les vortex peuvent être supprimés en augmentant la profondeur d'immersion, mais en gardant $Q$ inchangé. La comparaison entre les figures 4 et 5 , quand elle est possible, montre que le paramètre de circulation était plus faible pour la prise horizontale que pour la prise inversée vecticalement quand les deux prises fonctionnaient avec les mêmes paramètres d'écoulement $Q$ et $h$. Ceci est dû au fait que, pour le second type de prise, le noyau d'air était plus long, ce qui implique une valeur de $\Gamma$ plus élevée que dans le cas d'une prise horizontale. Les figures 4 et 5 montrent également que le paramètre de circulation et $R_{R}$ sont indépendants de la géométrie de la prise exprimée par $\frac{x}{D}$ et $\frac{b}{D}$. On peut donc en conclure que le paramètre de circulation et le nombre de Reynolds radial déterminent la formation des vortex de surface à partir du moment où la géométrie de la prise a créé la circulation nécessaire.

\section{Effet de la tension superficielle}

Il a été mentionné que, pour démontrer l'effet de la tension superficielle représenté par $W$ (voir équation 2), il est essentiel d'inclure la circulation $\Gamma$ à laquelle correspond le paramètre de circulation $\frac{\Gamma r_{0}}{Q}$. C'est pourquoi la courbe de ce paramètre en fonction du nombre de Weber est tracée dans les figures 6 et 7 pour les deux types de prises étudiées ici. Dans la figure 6 apparaissent également les résultats des dépressions peu profondes et profondes, respectivement avec $\frac{h_{d}}{h}=0,01$ et 0,1 . Les figures 6 et 7 montrent clairement que l'effet de la tension superficielles sur les vortex devient apparent dès qu'une dépression se produit à la surface libre. La fossette devient moins sensible à la variation du nombre de Weber quand $W>1,5 \times 10^{4}$, ce qui correspond aux ters, representing the effect of circulation and of the fluid viscosity are acceptable.

Figures 4 and 5 show that the circulation number rapidly decreases at first with the increase of the radial Reynolds number; its variational change becomes slower with further increase of $R_{R}$, and figure 5 shows clearly that the circulation number never becomes independent of the radial Reynolds number. A result which confirms the assumption made previously that the flow in a vortex is of laminar type affected always by the fluid viscosity. These figures further show the boundaries between three regions namely strong vortices with large air cores, vortices with slender air cores, and dimple region. These three types of vortices can occur for various values of the radial Reynolds number $R_{R}$ when the circulation parameter is low: a distinct possibility that this can occur in model studies of a small scale [10] in which the circulation parameter is usually low. Figures 4 and 5 further show that the vortices can be suppressed by increasing the submergence depth but keeping $Q$ the same. Comparison between figure 4 and figure 5, where applicable, shows that the circulation number for the horizontal intake was lower than for the vertically inverted intake when both were operating under the same flow parameters $Q$ and $h$. This is due to the fact that the air core for the second type of intake was longer, requiring a higher value of $\Gamma$ as compared with the case for a horizontal intake. Figures 4 and 5 further show that the circulation number and $R_{R}$ are independent of the intake geometry expressed by $\frac{x}{D}$ and $\frac{b}{D}$. It can therefore be concluded that the circulation number and the radial Reynolds number determine the onset of free surface vortices once the intake geometry has created the necessary circulation.

\section{Surface tension effect}

It has been mentioned that in order to demonstrate the effect of surface tension described by W (see Eq (2)) it is essential to include the circulation $\Gamma$, for which the circulation parameter $\frac{\Gamma r_{0}}{Q}$ is appropriate. Hence this parameter is plotted against the Weber number in figures 6 and 7 for the two types of intakes investigated here. In figure 6 are also shown the results of shallow and deep dimples with $\frac{h_{d}}{h}=0.01$ and 0.1 respectively. Figures 6 and 7 show clearly that the effect on vortices of surface tension becomes apparent as soon as a depression occurs at the free surface. The dimple becomes less sensitive to Weber number variation when $W>1.5 \times 10^{4}$, representing the cases in which the free surface curvature becomes small. The value of $W$ 


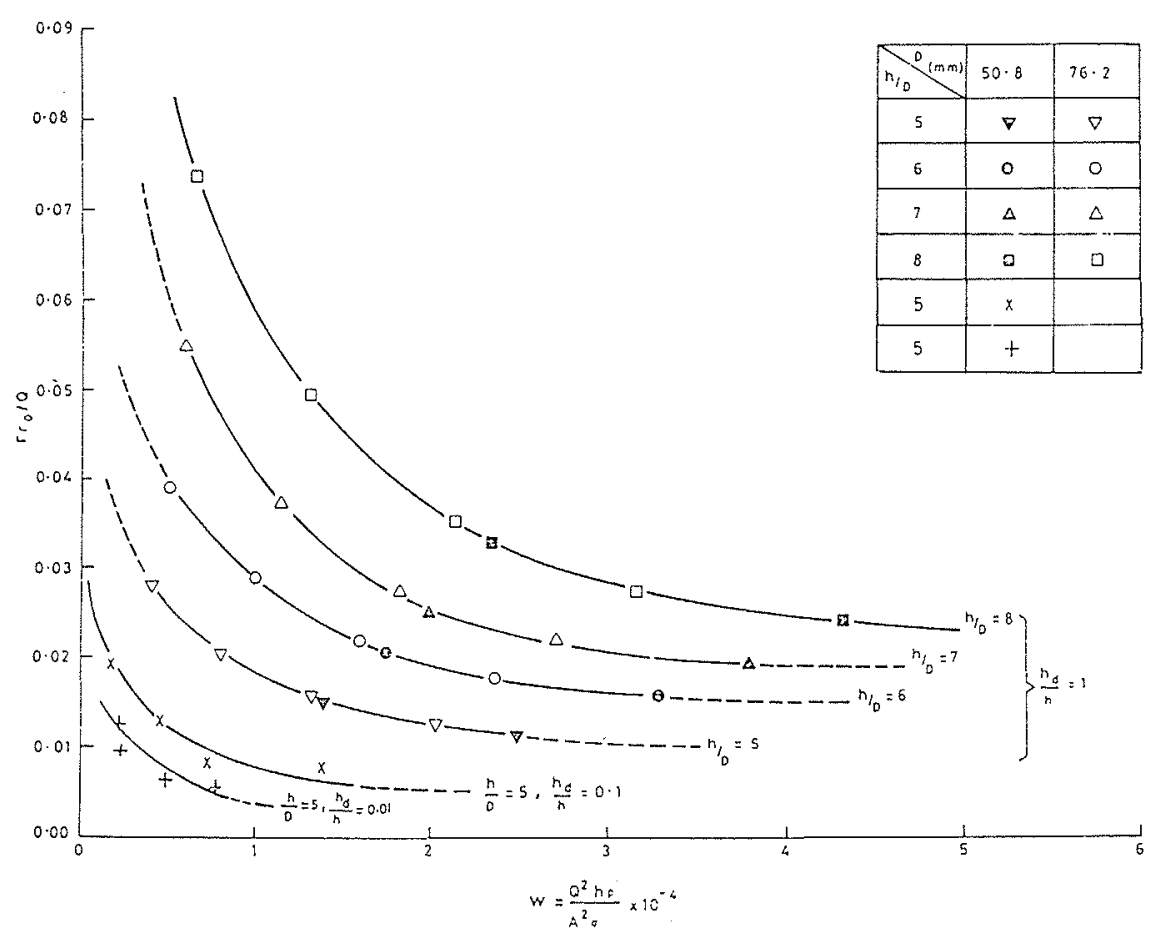
Figure $6-$ Weber number effect on free surface vortex with and without air core at horizontal intake, $\frac{1}{4} \leqslant \frac{x}{D} \leqslant 4, x=0$
and $0.30 \mathrm{~m}$.

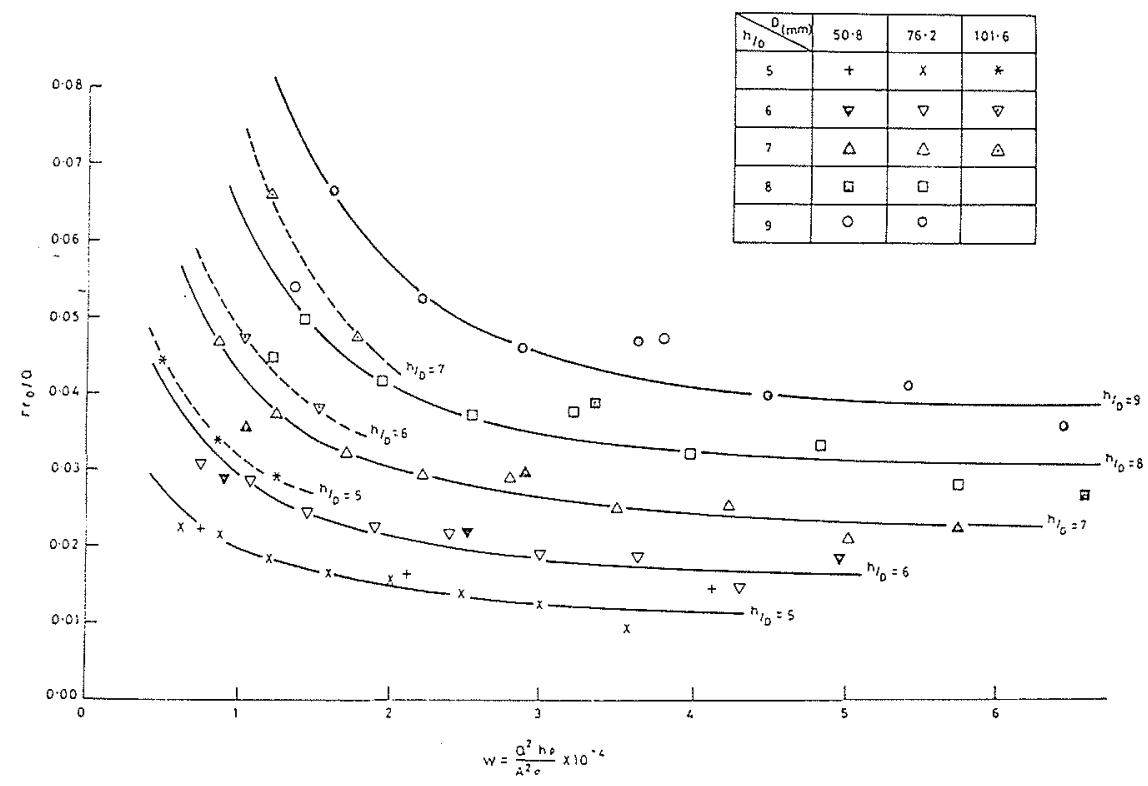

Figure 7 - Weber number effect on free surface vortex at vertically inverted intake, $\frac{1}{4} \leqslant \frac{d}{D} \leqslant 4,1 \leqslant \frac{x}{D} \leqslant 9$.

cas où la courbure de la surface libre devient faible. La valeur de $W$ croît jusqu'à $4 \times 10^{4}$ pour le type de vortex étudié ici (Cf. fig. 1). Il est intéressant de noter que les résultats illustrés par ces figures dépendent également de $\frac{h}{D}$ (ou de $\frac{r_{0}}{h}$, non représenté dans l'article), mais pas dans le cas de l'effet de la force de viscosité, comme le increases to $4 \times 10^{4}$ for the type of vortices studied here (see fig. 1). It is interesting to note that the results shown in these figures depend on $\frac{h}{D}$ as well (or $\frac{r_{0}}{h}$ not shown in the paper), but not in the case of viscous force effect as presented in figures 4 and 5. This submergence dependency in the surface tension case is due to the 
montrent les figures 4 et 5 . Cette dépendance de l'immersion dans le cas de tension superficielle est due à la variation linéaire de $W$ avec $h$, de sorte qu'un accroissement de $h$ entrainera :

a) un accroissement linéaire de $W$ ainsi que de $\frac{h}{D}$ pour un $D$ donné,

b) un accroissement de $r_{0}$ et $\Gamma$ (Cf. Equations (4) et (3), afin d'obtenir un type défini de vortex - voir exemple figure 1.

Par ailleurs, les mesures ont montré $[2,3,11,29]$ que les courbes de vitesses dans les vortex ne sont pas affectées par l'existence d'un noyau d'air ou d'une fossette. On peut voir finalement que les résultats représentés par les figures 6 et 7 sont indépendants de la géométrie de la prise exprimée par $\frac{x}{D}$ et $\frac{b}{D}$.

\section{Rendement de la prise}

Il a été montré jusqu'ici que les effets sur des vortex à paramètre de circulation $\Gamma r_{0} / Q$ des paramètres non dimensionnels renfermant les forces de viscosité et de tension superficielle ont été considérés comme des paramètres indépendants.

L'effet du paramètre de circulation sur le paramètre dépendant $C=Q / A \sqrt{2 g h}$, rendement de la prise, a été déterminé en traçant la courbe de $C$ en fonction de $\Gamma r_{0} / Q$, et les résultats apparaissent sur les figures 8 et 9 , à la fois pour les prises horizontales et pour les prises inversées verticalement. On peut voir que le coefficient crôit quand le paramètre de circulation décroit. Les figures 8 et 9 montrent également que les deux linear variation of $W$ with $h$, so that an increase in $h$ will cause

(a) a linear increase in $W$ and also in $\frac{h}{D}$ for a given $D$;

(b) an increase in $r_{0}$ and $\Gamma$ (see Eqs (4) and (3)) in order to obtain a definite type of vortex, see figure 1 for example.

On the other hand, measurments showed [2, 3, 11,291 that the velocity profiles in vortices are not affected by the existence of an air core or a dimple. Finally it can be seen that the results shown in figures 6 and 7 are independent of the intake geometry described by $\frac{x}{D}$ and $\frac{b}{D}$

\section{Intake efficiency}

So far it has been shown the effects of the non-dimensional parameters containing viscosity and surface tension forces on vortices having the circulation parameter $\Gamma r_{0} / Q$, have been considered as independent parameters.

The effect of the circulation parameter on the dependent parameter $C=Q / A \sqrt{2 g h}$, the intake efficiency, was determined by plotting $C$ against $\Gamma r_{0} / Q$ and the results are shown in figures 8 and 9 for both horizontal and vertically inverted intakes. It can be seen that the coefficient $C$ increases with the decrease of the circulation parameter. Figures 8 and 9 further show that both

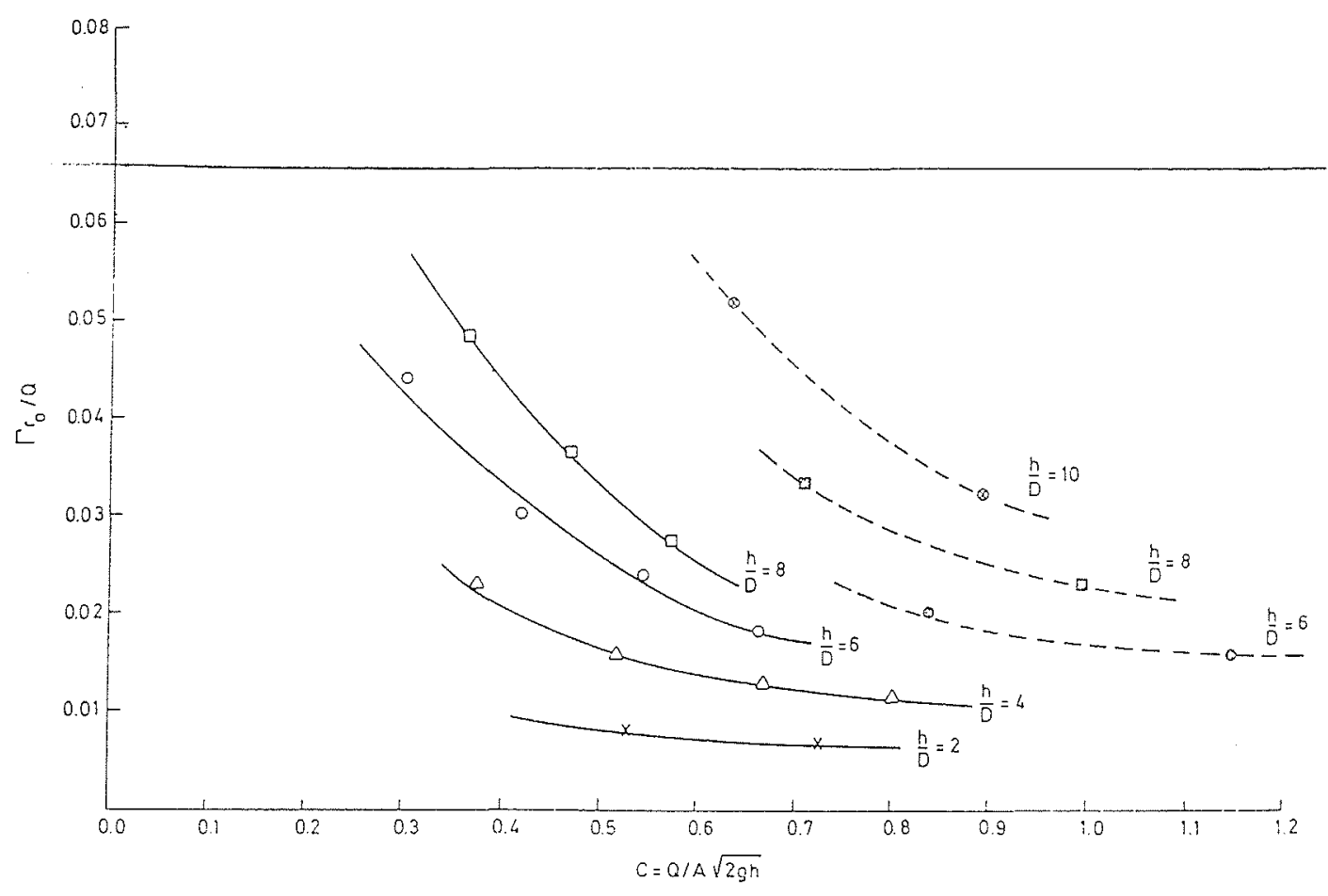

Figure 8 - Variation of discharge coefficient due to free surface vortices at horizontal intake. $\quad D=76.2 \mathrm{~mm}, \quad D=50.8 \mathrm{~mm}$. 


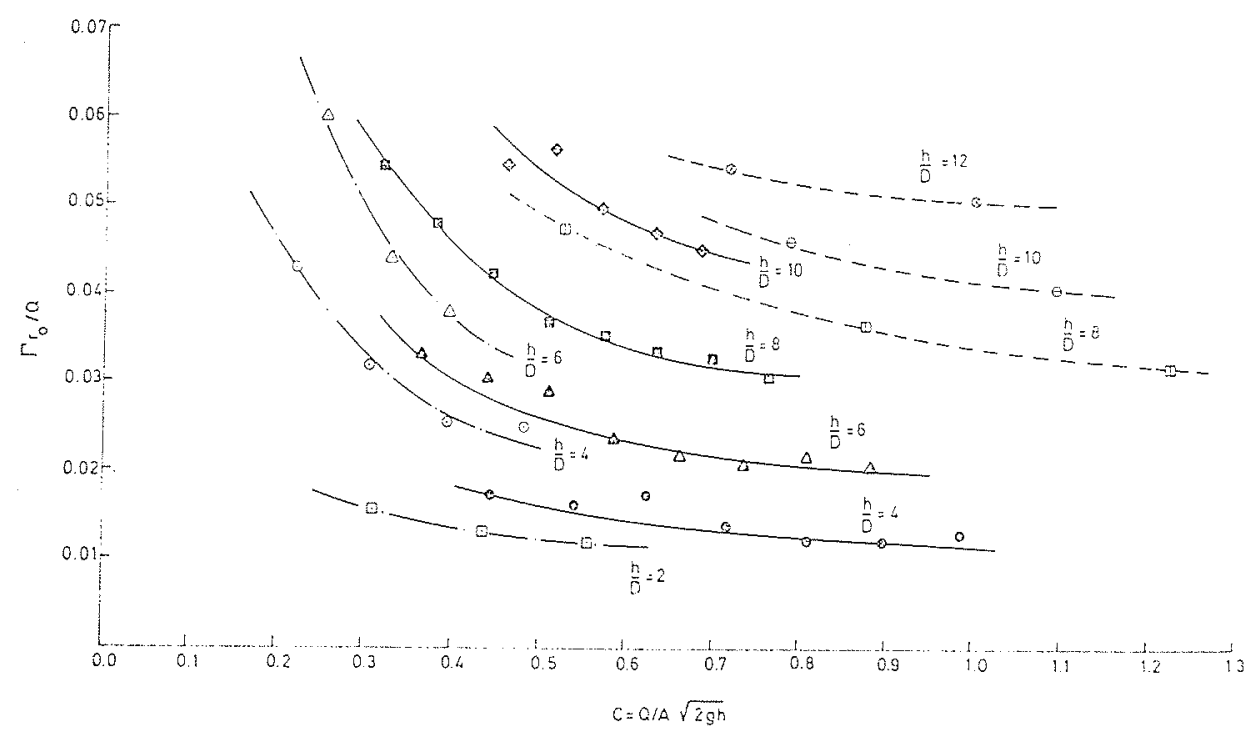

Figure 9 - Variation of discharge coefficient due to free surface vortices at vertically inverted intake. $D=76.2 \mathrm{~mm}, \quad D=101.6 \mathrm{~mm}, \quad D=50.8 \mathrm{~mm}$.

paramètres varient avec le paramètre d'immersion $\frac{h}{D}$, et à un degré moindre avec le diamètre de l'arrivée $D$ (Cf. fig. 9), résultat qui a été obtenu également par d'autres chercheurs $[7,9,10,19]$. Les mesures ont aussi montré que, dans le cas des prises inversées verticalement, la valeur de $C$ décroit quand $\frac{x}{D}$ augmente, et devient presque indépendante de ce paramètre quand $\frac{x}{D}>5$. Le coefficient $C$ pour la prise horizontale est resté inchangé quand on a fait varier $\frac{x}{D}$. Le coefficient $C$ a également varié avec la distance du fond quand le paramètre de distance $\frac{b}{D}$ était inférieur à 4 ou à 2 respectivement pour les prises horizontales et inversées verticalement.

\section{Vortex internes}

On a observé la formation de vortex internes entre le fond du canal et les prises des deux types étudiés ici. Ces vortex extrayaient l'air dissous de l'eau et étaient assez forts pour aspirer des particules du fond. On a trouvé que les vortex internes se formaient quand la vitesse dans la prise était élevée, ou lorsque la profondeur d'immersion était faible, ou lorsque ces deux conditions étaient réunies. Leur formation a été trouvé indépendante de celle des vortex de surface libre, et ils peuvent par conséquent apparaitre soit séparément, soit en même temps que ces derniers. L'intensité des vortex internes était réduite, et dans certains cas ils furent entièrement éliminés en rendant rugueux le fond du canal à l'aide de métal déployé. Tullis [28] discute d'autres méthodes pour supprimer ce genre de vortex. pararneters vary with the submergence parameter $\frac{h}{D}$ and to a lesser extent with the intake diameter D, (see fig. 9), a result which was also obtained by other research workers [7, 9, 10, 19]. Measurements further showed that in the case of vertically inverted intakes the $C$ value decreases with increasing $\frac{x}{D}$, (it becomes almost independent of this parameter when $\frac{x}{D}>5$ ). The coefficient $C$ for the horizontal intake remained unchanged when $\frac{x}{D}$ was varied. The coefficient $C$ also varied with the floor clearance, when the clearance parameter $\frac{b}{D}$ was less than 4 and 2 for the horizontal and vertically inverted intakes respectively $[4,7,19]$.

\section{Subsurface vortices}

Subsurface vortices were observed to form between the flume floor and intakes of both types studied here. These vortices drew dissolved air out of water and were strong enough to pick up particles from the floor. It was found that the subsurface vortices formed when the intake velocity was high or the submergence depth was shallow, or a combination of both. The conditions for their formation were found to be independent of the free surface vortices, and therefore they could appear either separately or together with free surface vortices. The strength of the subsurface vortices were reduced and in some cases they were eliminated altogether by roughening the flume floor with expanded metal mesh. Tullis [28] discusses other methods for eliminating such vortices. 


\section{Conclusions}

La formation de vortex de surface libre à proximité des prises d'eau peut aussi provoquer de la cavitation et des vibrations dans l'appareillage hydraulique et dans les installations connexes. Des études sur modèle réduit d'après un schéma proposé sont donc nécessaires pour examiner les conditions d'écoulement amont, ainsi que la formation de vortex.

Afin de déterminer la mesure dans laquelle les essais sur modèle réduit peuvent être acceptés comme représentatifs des conditions du prototype, des vortex de surface libre ont été formés avec des prises horizontales et inversées verticalement, et les expériences ont été faites avec divers écartements entre la prise d'une part, le fond et la paroi arrière d'autre part. Les paramètres non dimensionnels représentant la viscosité du fluide, la tension superficielle, le rendement de la prise en présence de vortex, et la géométrie de la prise, ont été déterminés expérimentalement. Les résultats montrent qu'il est possible d'obtenir des représentations universelles des valeurs relevées en faisant usage de ces paramètres. Ils indiquent également que les vortex de surface libre sont toujours affectés par la viscosité du fluide d'essai, et que l'effet de la tension superficielle est apparent dès qu'une dépression apparait à la surface libre. Les paramètres mesurés, c'est-à-dire le paramètre de circulation et le coefficient de débit, deviennent moins sensibles à la variation du nombre de Reynolds radial quand ce dernier est supérieur à $10^{5}$ dans le cas d'une prise inversée verticalement. Pour les prises horizontales, la limite supérieure du nombre de Reynolds radial accessible avec le présent dispositif expérimental était de $4 \times 10^{4}$. Au-delà de cette valeur, on a constaté que le paramètre du vortex dépendait fortement de la variation du nombre de Reynolds radial pour les deux types de prises. A la lumière des résultats obtenus dans la présente étude, il semble raisonnable d'admettre qu'une limite d'environ $10^{5}$ pour $R_{R}$ est également acceptable pour les prises horizontales.

Les paramètres mesurés sont moins sensibles à une variation du nombre de Weber quand ce dernier est supérieur à $4 \times 10^{4}$, tant pour les prises horizontales que pour les prises inversées verticalement. Il est intéressant de noter que, pour les deux types de prises, le paramètre de circulation, le nombre de Reynolds radial, et le nombre de Weber, sont indépendants des paramètres renfermant la géométrie de la prise.

Le coefficient de débit n'est pas affecté par le paramètre hauteur de la prise quand celui-ci est supérieur à 4 pour une prise horizontale et à 2 pour une prise inversée verticalement.

L'orifice divergent avait peu d'effet direct sur la formation des vortex de surface libre, mais améliorait le rendement de la prise.

\section{Remerciements}

Les travaux décrits dans cet article ont été effectués dans le cadre d'un programme de recherches de la Sta-

\section{Summary}

The onset of free surface vortices at hydraulic intakes can also cause cavitation and vibration in hydraulic machinery and its associated structures. Physical model studies on a proposed layout are, therefore, required to examine the flow conditions of the incoming water and also the likelihood of vortex formation.

In order to establish the range over which the results of model tests can be accepted as being representative of prototype conditions, free surface vortices have been formed at horizontal and vertically inverted intakes, and the experiments were carried out with various intake clearances from the floor and from the rear end wall. The non-dimensional parameters, representing fluid viscosity, surface tension, intake efficiency in the presence of vortices and the intake geometry were determined experimentally. The results show that it is possible to obtain universal representations of the measured data by making use (of the measured data by making use) of these parameters. The results also indicate that free surface vortices are always affected by the viscosity of the test fluid, and that the effect of the surface tension is apparent as soon as a depression at the free surface occurs. The measured parameters i.e. the circulation parameter and the coefficient of discharge, become less sensitive to the variation of the radial Reynolds number when it is larger than $10^{5}$ in the case of a vertically inverted intake. For horizontal intakes the upper limit of the radial Reynolds number allowed by the present experimental set up was $4 \times 10^{4}$, over which the vortex parameter was found to be strongly dependent on the variation of the radial Reynolds number for both types of intakes. In the face of results obtained from the present study it is reasonable to assume that a limit of about $10^{5}$ for $R_{R}$ is acceptable for horizontal intakes as well.

The measured parameters are less sensitive to a variation of the Weber number when it is larger than $4 \times 10^{4}$ for both horizontal and vertically inverted intakes. It is interesting to note that for both types of intakes the circulation parameter, the radial Reynolds number and the Weber number are independent of the parameters containing the intake geometry.

The coefficient of discharge is not affected by the intake height parameter when this is greater than 4 for a horizontal intake and 2 for a vertically inverted in take.

The bellmouth entry had little direct effect on the onset of free surface vortices, but it improved the intake efficiency.

\section{Acknowledgements}

The work described in this paper was carried out as part of a research programme of the Hydroulics Research 
tion de Recherches Hydrauliques, et cet article est publié avec l'autorisation du Directeur de la Station.

L'auteur souhaite exprimer ses remerciements au Dr. T.J. Weare et à Mr. A.F. Vhillock pour leur intérêt et leurs obligeants commentaires, ainsi qu'à Mr. M.B. Amphlett pour le soin qu'il a apporté aux mesures.

\section{Notation}

Les symboles suivants ont été utilisés dans cet article :

$A \quad$ section de la prise

$A_{c} \quad$ section de l'écoulement

$b$ hauteur de la prise

$C$ coefficient de débit, rendement de la prise

$D$ diamètre de la prise

$f$ fonction (Cf. Equation (1)

$g \quad$ accélération de la pesanteur

$h$ profondeur d'immersion dans l'eau

$h_{0}$ profondeur d'immersion totale, $h_{0}=h+b$

$Q \quad$ débit

$r$ rayon mesuré à partir de l'axe du vortex

$r_{0} \quad$ échelle radiale, rayon de l'ombre

$V \quad$ composante radiale de la vitesse

$V_{\theta} \quad$ composante tangentielle de la vitesse

$W \quad$ nombre de Weber

$x$ distance à partir de la cloison arrière ou latérale

$\alpha \quad$ constante non dimensionnelle (Cf. Equation (3)

$\alpha_{H}, \alpha_{V}$ constante empirique pour les prises horizontales et inversées verticales

$\beta_{H}, \beta_{V}$ relation empirique

et inversées verticales

$\Gamma \quad$ circulation $\Gamma=V_{\theta} r$

$\theta \quad$ angle de la spirale logarithmique

$\rho \quad$ masse spécifique

$\sigma \quad$ tension superficielle
Station and the paper is published by permission of the Director of the Station.

The writer wishes to express his thanks to $\mathrm{Dr} T \mathrm{~J}$ Weare and $M r A F$ Whillock for their interest and helpful comments and further thanks to $\mathrm{Mr} M B$ Amphlett for his careful measurements.

\section{Notation}

The following symbols are used in this paper:

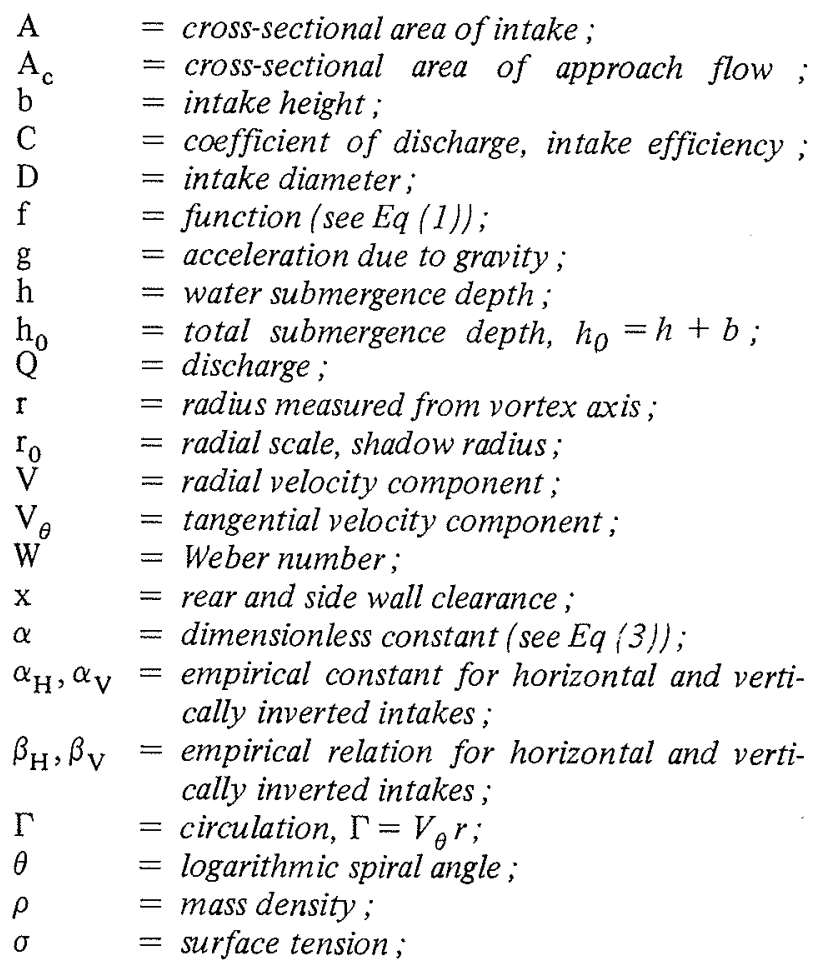

\section{Réferences - Bibliographie}

[1] ANWAR H.O. - "Vortices in a viscous fluid", J. of Hyd. Res., Vol. 6, No. 1, 1968, pp. 1-14.

[2] ANWAR H.O. - "Formation of a weak vortex", J. of Hyd. Res., Vol. 4, No. 1, 1966, pp. 1-16.

[3] ANWAR H.O. - "Prevention of vortices at intakes", Water Power, Vol. 10, No. 1, 1968, pp. 303-402.

[4] ANWAR H.O. and AMPHLETT M.B. - "Vortices at vertically inverted intake", J. of Hyd. Res., Vol. 18, No. 2, 1980, pp. 123-134

[5] ANWAR H.O. - Discussion of "Experiments on unstable vortices" by Levi, E., Proc. ASCE, Vol. 99, No. EM1, 1973, pp. $227-228$.

16] BERGE J.P. - "A study of vortex formation and other abnormal flow in a tank with and without a free surface", La Houille Blanche, Vol. 21, No. 1, 1966, pp. 13-40.

[7] CHANG R. - "Experimental data on the hydraulic design of intakes and rectangular pump sumps", British Hydromech. Res. Ass. Report No. RR 1518, January 1979.

[8] DAGGETT L.L. and KEULEGAN G.H. - "Similitude in free vortex formation", Proc. ASCE, Vol. 100, No. HY11, Nov. 1974, pp. 1565-1581.

[9] DENNY D.F. and YOUNG G.A.J. - "The prevention of vortices and swirl at intakes", Proc. 7th IAHR Congr., Paper No. C-1, Lisbon, Portugal, 1957, See also BHRA, Publications No. SP 583, July 1957.

[10] DHILLON G.S. - "Vortex formaton at pipe intakes and its prediction - Status Report", No. 6, Irrigation and Power Res. Inst., Punjab Amritsar, India, January 1980.

[11] DONALDSON C. DUP. and SULLIVAN R.D. - "Behaviour of solution of the Navier-Stokes equations for a complete class of three-dimensional viscous vortices". Proc. Heat Transfer and Fluid Mech. Inst., Standford U. Press, May 1960, pp. 16-30.

[12] DURGIN W.W. and HECKER G.E. - "The modelling of vortices at intake structure", Joint Symposium on design and operation of fluid machinery, ASME-ASCE, Colorado State University, June 1978.

[13] DURGIN W.W., NEALE L.C. and CHURCHILL R.L. - "Hydrodynamics of vortex suppression in the reactor building sump decay heat removal system, Three Mile Island Nuclear St., Unit "2", ARL Ref. No. 46-77/M2O2FF, February 1977.

[14] EINSTEIN H.A. and LI H. - "Steady vortex flow in a real fluid", La Houille Blanche, Vol. 10, No, 4, August 1955, pp. 483-497.

[15] GARDINER I. and EVERS M. - "Prattsville pumped storage project, Model study of the upper reservoir intake", Hyd. Res. Station, Wallingford, Rep. No. EX 799, November 1978.

[16] GRANGER R. - "Steady three-dimensional vortex flow", J. Fluid Mech., Vol. 25, Part 3, 1966, pp. 557-576.

[17] HECKER G.E. - "Model-prototype comparison of free surface vortices", (in press).

[18] HUGHES R.L. - Discussion of "Similitude in free surface vortex formation", by Dagget and Keulegan, Proc. ASCE, Vol. 101, HY9, September 1975, pp. 1287-1289. 
[19] IVERSON H.W. - "Studies of submergence requirements of high specific speed pumps", University of California, Inst. of Eng. Res., May 1953, Also: Trans. ASME, Vol. 15, No. 4, May 1953, pp. 635-641.

[20] KOHLHASE S. - "Ueber den Vordrall on pumpeneinlaeufen in wirbelfeld", Mitt. Frauzius Inst. fuer Wasserbau \& Kuest. Tech. Univ. Hannover, Heft 38, 1973.

[21] KOLF R.C. - "Vortex flow through horizontal orifices", Trans. ASCE, Vol. 124, Paper No. $3004,1959$.

[22] LEVI E. - "Experiments on unstable vortices", ASCE, Vol. 98, AM3, June 1972, pp. 539-559.

[23] LEWELLEN W.S. - "A solution for three-dimensional vortex flow with strong circulation", J. Fluid Mech., Vol. 14, Part 3, 1962, pp. $420-432$.

[24] LOADER A.J. and THEW M.T. - "Vortex flow study", Prog. Rep. No. 6, Dept. of Mech. Eng., Univ. of Southampton, Ref. No. ME/75/23, January 1976.

[25] PENNINO B.J. and HECKER G.E. - "A synthesis of model data for pumped storage intakes", Trans. ASME, Symp. on pump/ turbine schemes, June 1979.

[26] STEVENS J.C. and KOLF R.C. - "Vortex flow through horizontal orifice", Proc. ASCE, Vol. 83, No. SA6, December 1957, pp. $1-21$.

[27] THEW M.T. and BLACKMORE C. - "Vortex flow study", Prog. Rep. No. 2, June-September 1973, Southampton Univ. Dept. of Mech. Eng., Rep. No. ME/73/29, December 1973.

[28] TULLIS J.P. - "Modeling in design of pumping pits", Proc. ASCE, Vol. 105, No. HY9, September 1979, pp. $1053-1063$.

[29] TURNER J.S. - "The constraints imposed on tornado-like vortices by the top and bottom boundary conditions", J. Fluid Mech., Vol. 25, Part 2, 1966, pp. 377-400.

[30] WELLER J.A. - Discussion of "Similitude in free-surface vortex formation" by Daggett, L.L. and Keulegan, G.H., Proc. ASCE, Vol. 101, No. HY11, November 1975, pp. 1449-1451. 